\title{
Carbon footprint of Canadian dairy products: Calculations and issues
}

\author{
X. P. C. Vergé, ${ }^{* 1}$ D. Maxime,† J. A. Dyer, ${ }^{* 2}$ R. L. Desjardins, ${ }^{\star 3}{ }^{3}$ Y. Arcand, $\ddagger$ and A. Vanderzaag* \\ ${ }^{*}$ Agriculture and Agri-Food Canada, Ottawa ON, K2A 1G6, Canada \\ †Interuniversity Research Centre for the Life Cycle of Products, Processes and Services (CIRAIG), Polytechnique Montréal, Montréal QC, \\ H3C 3A7, Canada \\ $\ddagger$ Agriculture and Agri-Food Canada, Cambridge ON, N3H 3Z9, Canada \\ $\S$ Eastern Cereal and Oilseed Research Centre, Agriculture and Agri-Food Canada, Ottawa ON, K1A 0C6, Canada \\ $\ddagger$ Food Research and Development Centre, Saint-Hyacinthe QC, J2S 8E3, Canada
}

\begin{abstract}
The Canadian dairy sector is a major industry with about 1 million cows. This industry emits about 20\% of the total greenhouse gas (GHG) emissions from the main livestock sectors (beef, dairy, swine, and poultry). In 2006, the Canadian dairy herd produced about 7.7 Mt of raw milk, resulting in about $4.4 \mathrm{Mt}$ of dairy products (notably $64 \%$ fluid milk and $12 \%$ cheese). An integrated cradle-to-gate model (field to processing plant) has been developed to estimate the carbon footprint $(\mathrm{CF})$ of 11 Canadian dairy products. The on-farm part of the model is the Unified Livestock Industry and Crop Emissions Estimation System (ULICEES). It considers all GHG emissions associated with livestock production but, for this study, it was run for the dairy sector specifically. Off-farm GHG emissions were estimated using the Canadian Food Carbon Footprint calculator, (cafoo) $)^{2}$-milk. It considers GHG emissions from the farm gate to the exit gate of the processing plants. The $\mathrm{CF}$ of the raw milk has been found lower in western provinces $\left[0.93 \mathrm{~kg}\right.$ of $\mathrm{CO}_{2}$ equivalents $\left(\mathrm{CO}_{2} \mathrm{e}\right) / \mathrm{L}$ of milk] than in eastern provinces $\left(1.12 \mathrm{~kg}\right.$ of $\mathrm{CO}_{2} \mathrm{e} / \mathrm{L}$ of milk) because of differences in climate conditions and dairy herd management. Most of the $\mathrm{CF}$ estimates of dairy products ranged between 1 and $3 \mathrm{~kg}$ of $\mathrm{CO}_{2} \mathrm{e} /$ $\mathrm{kg}$ of product. Three products were, however, significantly higher: cheese $\left(5.3 \mathrm{~kg}\right.$ of $\left.\mathrm{CO}_{2} \mathrm{e} / \mathrm{kg}\right)$, butter $(7.3$ $\mathrm{kg}$ of $\left.\mathrm{CO}_{2} \mathrm{e} / \mathrm{kg}\right)$, and milk powder $\left(10.1 \mathrm{~kg}\right.$ of $\mathrm{CO}_{2} \mathrm{e} /$ $\mathrm{kg}$ ). The CF results depend on the milk volume needed, the co-product allocation process (based on milk solids content), and the amount of energy used to manufacture each product. The GHG emissions per kilogram of protein ranged from 13 to $40 \mathrm{~kg}$ of $\mathrm{CO}_{2} \mathrm{e}$. Two products had higher values: cream and sour cream, at 83 and

Received January 9, 2013.

Accepted May 15, 2013.

${ }^{1}$ Agro-environmental consultant, Ottawa, ON, K2A 1G6, Canada.

${ }^{2}$ Agro-environmental consultant, Cambridge, ON, N3H 3Z9, Canada.

${ }^{3}$ Corresponding author: Ray.Desjardins@agr.gc.ca
\end{abstract}

$78 \mathrm{~kg}$ of $\mathrm{CO}_{2} \mathrm{e} / \mathrm{kg}$, respectively. Finally, the highest $\mathrm{CF}$ value was for butter, at about $730 \mathrm{~kg}$ of $\mathrm{CO}_{2} \mathrm{e} / \mathrm{kg}$. This extremely high value is due to the fact that the intensity indicator per kilogram of product is high and that butter is almost exclusively fat. Protein content is often used to compare the CF of products; however, this study demonstrates that the use of a common food component is not suitable as a comparison unit in some cases. Functionality has to be considered too, but it might be insufficient for food product labeling because different reporting units (adapted to a specific food product) will be used, and the resulting confusion could lead consumers to lose confidence in such labeling. Therefore, simple units might not be ideal and a more comprehensive approach will likely have to be developed.

Key words: dairy production, carbon footprint, modeling, Canadian dairy industry

\section{INTRODUCTION}

Over the last decade, anthropogenic greenhouse gas (GHG) emissions have come to be accepted as the main cause of climate change. To find and implement GHG mitigation strategies, international efforts during this period have been devoted to quantifying the main GHG and identifying their sources (Steinfeld et al., 2006; IDF, 2010; Environment Canada, 2012). Following its creation in 1989, the Intergovernmental Panel on Climate Change (IPCC) developed a standard methodology to estimate all GHG emissions from the major economic sectors (IPCC, 1996b, 2000, 2006), which is now used by most countries to estimate national GHG emissions (UNFCCC, 2012). These emission inventories have become the foundation of national policies on GHG mitigation strategies and international agreements. In Canada, agricultural GHG emissions account for approximately $8 \%$ of the nation's total emissions (Environment Canada, 2012), and mitigation measures are being investigated for their potential to reduce net 
emissions. However, inventories are poor tools to track how effective GHG mitigation strategies are because agroecosystems are complex biological systems characterized by variability among producers, localities, and time. Also, agricultural GHG inventories do not include fossil fuel $\mathrm{CO}_{2}$ emissions from energy use; these have been included with off-road traffic (IPCC, 1996a). Although smaller in magnitude than agricultural methane $\left(\mathrm{CH}_{4}\right)$ and nitrous oxide $\left(\mathrm{N}_{2} \mathrm{O}\right)$ emissions, farm energy is an essential part of the sector's GHG emissions budget (Dyer and Desjardins, 2007, 2009). Its omission means that, for example, implementation of reduced tillage practices that decrease fossil fuel $\mathrm{CO}_{2}$ emissions from tractors is not factored into the effects that farm management decisions have on agricultural GHG emissions. Also, considering the food chain as a whole, the dairy and meat processing sectors are known to be important energy consumers (Eide, 2002; Foster et al., 2006; Hopkins and Lobley, 2009) and may thus be responsible for high GHG emissions whenever fossil fuels are the main energy source. Compared with conventional farms, the primary energy demand for organic farms was found to be lower (Cederberg and Mattson, 2000; Williams et al., 2006). To better assess GHG emission estimates, calculations need to be integrated into comprehensive models combining both on-farm and off-farm GHG emissions and easily updated and responsive to policy scenarios.

Greenhouse gas emissions from the food processing industry have recently been estimated and intensity indicators calculated to follow year-to-year efficiency improvements within the food industries such as dairy industry or meat production and processing (Maxime et al., 2010).

Assessments of the GHG emission budgets have also been completed for the 4 largest livestock commodities in Canada - beef, dairy, swine, and poultry (Dyer et al., 2008; Vergé et al., 2007, 2008, 2009a,b). All sources of the 3 main agricultural $\mathrm{GHG}\left(\mathrm{CH}_{4}, \mathrm{~N}_{2} \mathrm{O}\right.$, and fossil fuel $\mathrm{CO}_{2}$ ) were accounted for. Many commodity-specific GHG sources have inter-commodity linkages and many of them stem from competition for arable land, crops, and other inputs as well as for market share. For example, satisfying diet requirements can lead to competition for feed grain, especially under intensive animal production. The livestock industries share arable land with food crops such as bread-quality wheat, and the use of agricultural land to produce biofuel feedstock is also becoming very important (Klein and LeRoy, 2007; Dyer et al., 2010a). Therefore, the holistic approach undertaken for each sector needs to be applied to the agricultural and processing systems as a whole.

The objective of this paper was to estimate the carbon footprint ( $\mathbf{C F}$ ) of the main Canadian dairy prod- ucts from cradle (farm production) to the exit gate of processing plants. Two different reporting units have been used (kilograms of product and kilograms of protein content). Results are presented and the issues and needs discussed.

\section{MATERIALS AND METHODS}

\section{Boundaries of the System and Model Overview}

Greenhouse gas emissions were estimated using an integrated model including on-farm production, the associated processing industries, and transportations from farms to processing plants. All downstream steps after the dairy plant are outside the scope of this study (i.e., distribution, retailing, consumer use, and end-oflife of packaging).

The calculator has a multi-module structure. The farm is the heart of the model and is linked to 3 other modules corresponding to the milk, meat, and egg commodities through transportation. The onfarm GHG calculations were done using the Unified Livestock Industry and Crop Emissions Estimation System (ULICEES) calculator (Vergé et al., 2012). It considers all GHG emissions associated with livestock production but, for this study, it was run for the dairy sector specifically. The off-farm GHG emission calculations were performed using the $(\mathrm{Cafoo})^{2}$-milk calculator (Maxime et al., 2011).

Within the boundaries of the study, the system can be detailed as presented in Figure 1. The off-farm model for dairy products starts at the farm gate and includes milk hauling. The dairy processing sector is considered as a whole and each dairy plant is assumed to produce all dairy products mentioned in Figure 1. Such a modeling approach has been motivated by the fact that yearly statistics on energy use are available at the dairy manufacturing level only and not by product.

\section{On-Farm Model}

The methodology used in this paper follows an approach similar to the commodity-specific assessments already completed and presented for the Canadian dairy (Vergé et al., 2007; Dyer et al., 2008), beef (Vergé et al., 2008), pork (Vergé et al., 2009a), and poultry industries (Vergé et al., 2009b). The ULICEES model was described in Vergé et al. (2012). Therefore, this section summarizes the methodology previously presented and mentions the changes that have been introduced.

The ULICEES model is based on the IPCC methodology (IPCC 2000, 2006) adapted to Canadian conditions by Vergé et al. (2006) for $\mathrm{CH}_{4}$ emissions and by Rochette et al. (2008) for $\mathrm{N}_{2} \mathrm{O}$ emissions. Carbon 


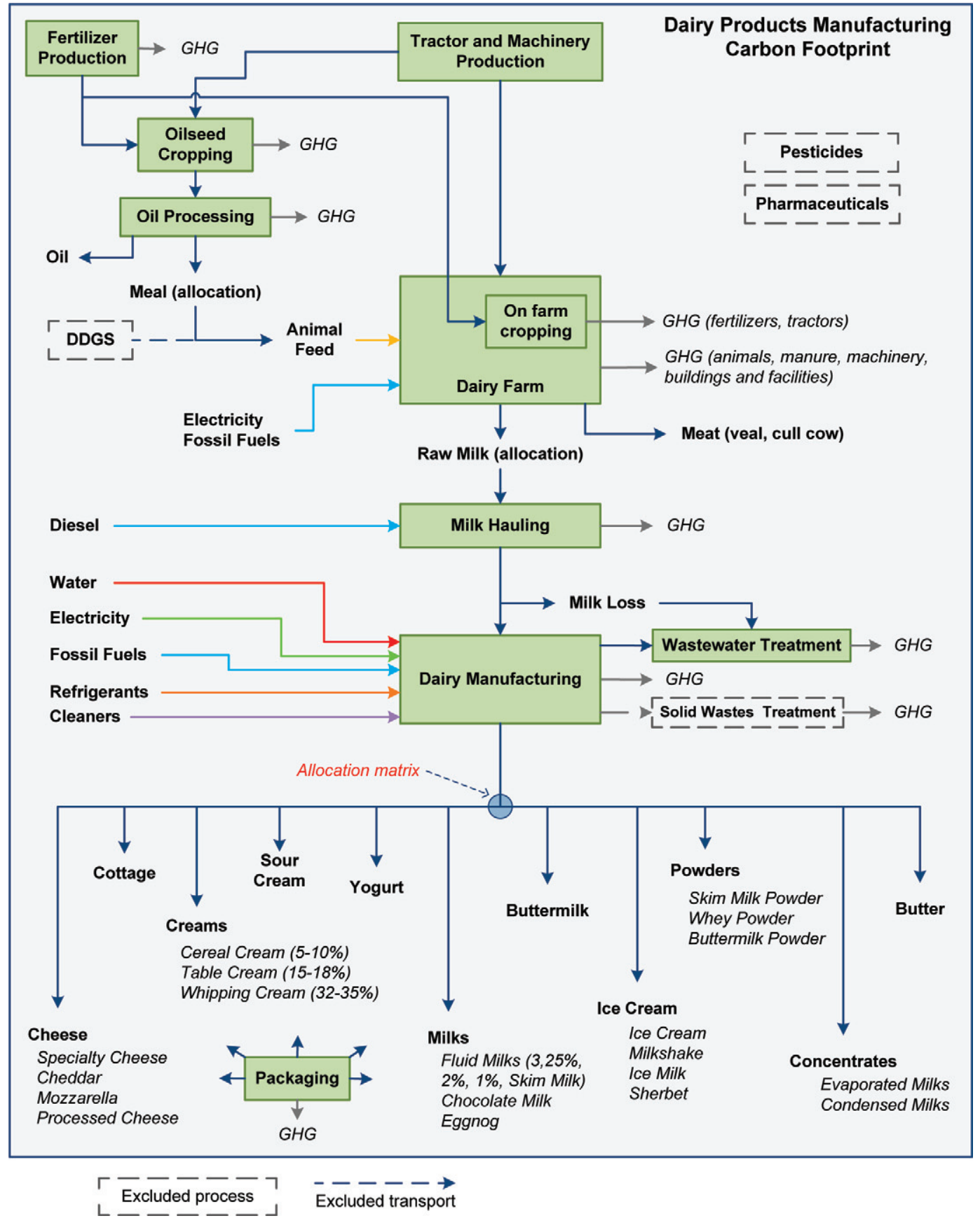

Figure 1. Dairy processing system: boundaries and calculation paths. DDGS = dried distillers grains with solubles; GHG = greenhouse gas Color version available in the online PDF.

dioxide emissions from fossil energy use were accounted for and calculated using the F4E2 model (Dyer and Desjardins, 2003).

Several terms have been revised from the 4 livestock assessments. These modifications, which resulted in minor differences compared with the 4 original livestock GHG emission budgets, concern animal diets and nitrogen excretion rates.
The crops in the animal diets were the same in ULICEES as used in the previous studies (Dyer et al., 2008; Vergé et al., 2007, 2008, 2009a,b), except for the addition of a mixed crop defined as "other small grains" in the Canadian agricultural census records. Although small, this crop class is used by the Alberta beef producers, the province where most Canadian beef is raised (Elward et al., 2003). 
The nitrogen excretion rates (voided organic nitrogen) are now animal specific. They are based on the volatile solid (VS) excretion instead of the American Society of Agricultural Engineers (ASAE) default N excretion rates (ASAE, 2003) only. Animal-specific VS:N ratios were calculated based on ASAE data and applied to the VS excretion estimations. These calculations were done for each commodity and all age-sex categories.

\section{Off-Farm Model}

Life Cycle Calculations. Life cycle inventory (LCI) was calculated for raw milk transportation from the dairy farm to the processing plant and for every dairy plant input mentioned above, except the production of raw milk, which was already treated as part of the on-farm analysis. To assist in modeling, we used the SimaPro 7.3.2 software (PRé Consultants, Amersfoort, the Netherlands). Most LCI data sets were based on the Ecoinvent LCI database ( $\mathrm{v} 2.2,2010$; www. ecoinvent.org/), and generic Ecoinvent data sets have been adapted to the Canadian context whenever relevant and possible to increase their representativeness of the geographical context of the study. This is especially the case for truck operation and for electricity supply, for which an electricity grid mix for 2006 has been modeled for every province. Furthermore, an average North American electricity grid mix was used for all background processes; that is, all processes directly or indirectly linked to the foreground processes (e.g., supply of chemicals, infrastructure production), considering that these activities may occur anywhere and most probably in North America.

Milk Transportation. Modeling of milk hauling was based on the Québec value (FPLQ, 2007) reported in Table 1 and used as a proxy for all other provinces because Québec was the only province where these data were available. In addition, it was the largest milk processing province in Canada (36\% of national volume in 2006).

Life cycle GHG emissions were calculated using an Ecoinvent process modified to reflect North American truck transportation. The pumping, cleaning, and disinfection of milk tank trucks were not accounted for because of lack of data. The intensity indicator, or emission factor, calculated for milk transportation was 13.6 $\mathrm{g}$ of $\mathrm{CO}_{2}$ equivalents $\left(\mathbf{C O}_{2} \mathbf{e}\right)$ per liter of milk hauled.

Table 1. Input and output flows for dairy processing in Canada, in 2006

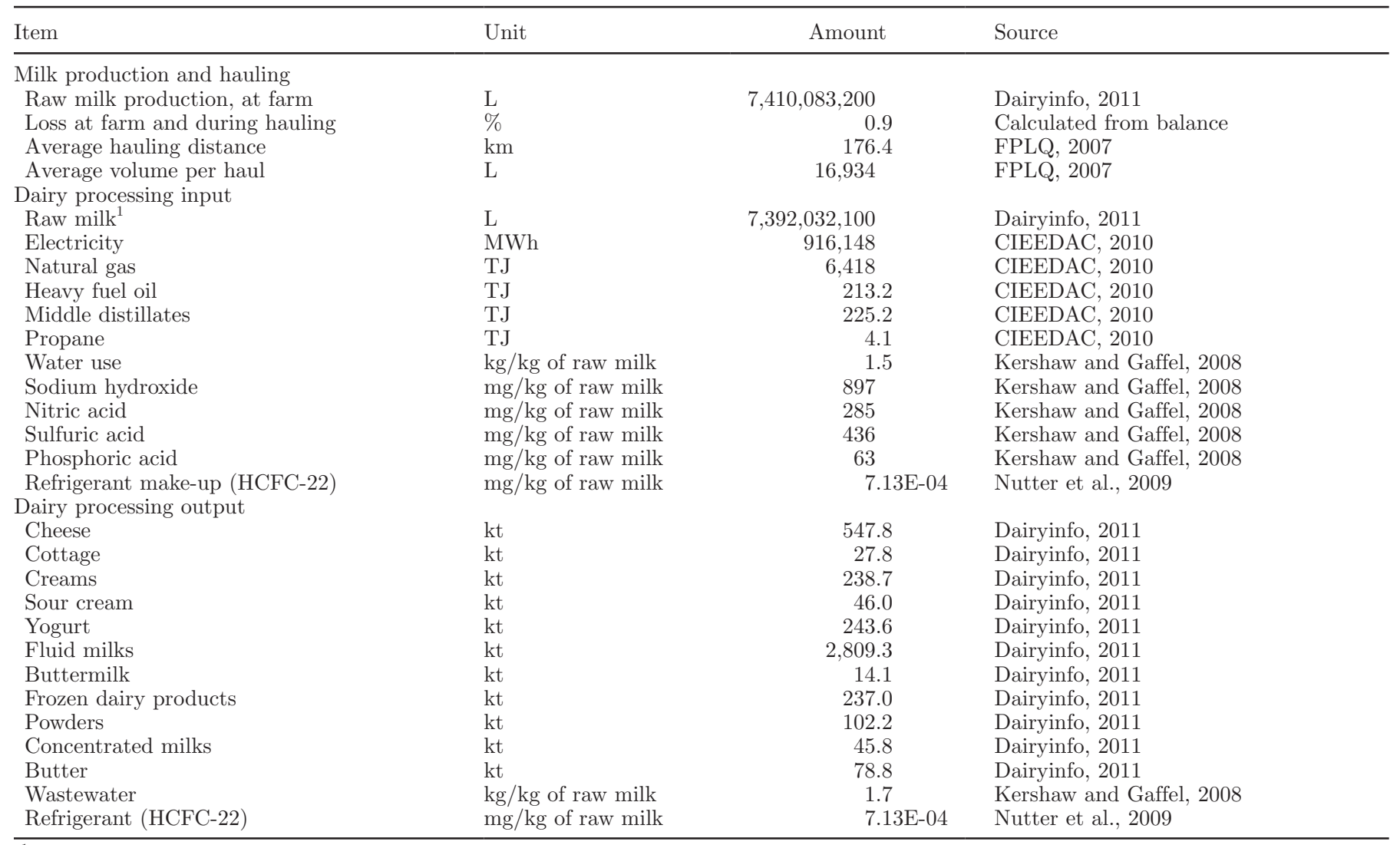

\footnotetext{
${ }^{1}$ Raw milk at $3.7 \%$ fat; specific gravity: $1.031 \mathrm{~kg} / \mathrm{L}$.
} 
Interprovincial exchanges of milk occurring through pooling agreements within Canada were considered. The trade of raw milk within the eastern provinces was accounted for [G. Rainville, Fédération des Producteurs Laitiers du Québec (FPLQ), Longueuil, QC, Canada, personal communication, 2011].

Dairy Product Processing Plants. Table 1 reports the input and output flows of Canadian dairy processing plants in 2006. Energy use data were obtained from the Canadian Industrial Energy End-Use Data and Analysis Centre (CIEEDAC, 2010) for the dairy products manufacturing sector (North-American Industry Classification System's industry no. 3115). Data are for all operations at plant, including conditioning, cleaning, and refrigerated storage.

National energy use data have been disaggregated based on the share of each province to the overall national raw milk input. Direct energy use is the main contributor to GHG emissions from dairy plants and, since specific Canadian energy consumption data of the dairy industry are used within the current model, the calculated GHG emissions are representative of the Canadian dairy industry. However, the same energy consumption per unit of raw milk processed and the same share of fuels were used across every province.

Losses occur in milking houses and during transportation. Milk is also discarded when animal diseases are detected. These losses make up the difference between yearly milk production calculated from the number of cows and the amount of milk actually processed in manufacturing plants. In 2006, for example, the difference was $0.9 \%\left(7.41 \times 10^{9}\right.$ vs. $7.34 \times 10^{9} \mathrm{~L}$; Dairyinfo, 2011). Other dairy processing input and output data were gathered from the international scientific and gray literature, with a preference given to national figures regarding water use, wastewater generation, caustic soda, and acid cleaners (Table 1). Consumption of packaging materials expressed in raw materials such as bleached paperboard, plastic resins (e.g., polypropylene, high-density polyethylene, low-density polyethylene, polystyrene), aluminum, corrugated board, cardboard (Brachfeld et al., 2001; CNE, 2007; British Columbia Dairy Council, 2008; Büsser and Jungbluth, 2009; Polytainers, 2012; TetraPak, 2012). Although packaging materials inventory is still underway, various packaging scenarios are provided within the model for fluid milks and yogurts. A generic average distance of $500 \mathrm{~km}$ for materials and chemicals supply was used, but the model allows for a sensitivity analysis with shorter and longer distances (200 and $800 \mathrm{~km}$ ). Data on solid residues (onsite packaging residues and organic residues not discarded with wastewater) are still to be collected.
Limitations and Potential Improvement of the Dairy Off-Farm Model. Inventory data for water use and wastewater generation, refrigerant and chemical use, and for some packaging (expected to be the third contributor to dairy products carbon footprint after milk production and onsite energy use) were generic data collected from the literature and industry reports worldwide. Emphasis was placed on finding either Canadian or US data, or data representative of the dairy industry of a whole country (e.g., the Australian dairy industry sustainability report), and avoiding specific data coming from only a few plants, as well as outdated data. Consequently, the technological representativeness of the Canadian dairy industry is only partial.

Because of the lack of provincial data on energy use and data gaps in dairy product outputs for each province, the provincial results, so far, have limitations. Hence, current provincial results differ mainly owing to the different electricity grid mix used and the consideration of interprovincial milk exchanges for some eastern provinces.

The provincial estimate is thus biased if the dairy product portfolio varies significantly from one province to another. It is unlikely that provincial data on energy use will be available from statistical sources because these data are confidential. Surveying plants or companies is an option but we anticipate reluctance of companies to provide data because of the high level of concentration in this sector ( $75 \%$ of the dairy market is held by only 3 groups). The most readily available improvement would be to assess the provincial dairy products' portfolio by addressing the few data gaps that have been found in statistics from the Canadian Dairy Commission.

Another limitation of the model is related to the lack of information about uncertainty for most of input data, especially for energy use data. Consequently, this issue has not been addressed yet within the study, and GHG estimates are expected to be representative averages, although provided without standard deviation.

Off-Farm GHG Emissions. Most of the off-farm emissions are $\mathrm{CO}_{2}$ emissions from the combustion of fossil energy - either diesel for transportation or natural gas or other fossil fuels used in industrial boilers. Also, the food industry is an intensive consumer of electricity (Maxime et al., 2010), the production of which leads to significant indirect GHG depending on the provincial electricity grid mix. The direct and indirect emissions from these energy sources were thus considered, as well as those from the supply of other inputs such as chemicals for cleaning operations, water, refrigerant makeup, and packaging materials. The model uses data from a life cycle inventory database that allows the capture 
of GHG emissions over the whole life cycle of these materials and utilities, including their transportation up to the food processing plant. Emissions of refrigerants that have a global warming potential are also accounted for. Emissions from food ingredients such as sugar, salt, stabilizers and other additives are not accounted for due to a lack of data.

\section{Co-Products and Allocation Approaches}

Overview. As illustrated in Figure 2, GHG emissions have to be allocated at different phases of production. Several of the processes accounted for are multifunctional, leading to co-products fulfilling different functions. This is the case for cattle feed production, in which vegetable oil is co-produced with canola and soybean meal, as well as for dairy system's co-products such as milk and meat from dairy farms (surplus calves and culled cows) and cream and fluid milk from fluid milk manufacturing plants. For dairy plant co-products, allocation is needed because, (1) the dairy manufacturing sector is considered as a whole, assuming all dairy plants are multi-output integrated plants delivering the dairy products portfolio; and (2) data on inputs (e.g., energy use) and products outputs for these processing sectors are only available at the aggregated level.

Allocation is an important step for any life cycle footprinting, and results depend highly on the chosen allocation rule (Feitz et al., 2007; Flysjö et al., 2009). The International Organization for Standardization
(ISO) standards 14040 series (ISO, 2006) proposes a hierarchy of approaches to the multifunctionality problem in life cycle assessment (LCA): (1) the subdivision of multifunctional processes as mono-functional processes with their own distinct inputs and outputs, (2) system expansion, and (3) allocation by splitting up the amount of the individual inputs and outputs between the co-functions according to allocation criterion, using a property of the co-functions (e.g., element content, energy content, mass, market price).

The subdivision approach is rarely possible for most of the processes (e.g., crude oil/cake from oilseed pressing; meat/milk from dairy cows; dairy products from multi-product integrated dairy plants). Although attractive, the system expansion approach significantly complicates the study and was not chosen here. First, it implies the identification of all marginal products, which is subject to some subjective economic assessment. Second, data collection is significantly greater and not necessarily available at the provincial level. Third, it can lead to tricky "looped" situations, especially in our case where a marginal product might actually be the coproduct of another of our subsystem (e.g., soybean oil might be the marginal product substituting for canola oil). Thus, allocations based on physical properties were preferred because they allow more comprehensive flow analyses that refer to a physical unit of products (e.g., $1 \mathrm{~L}$ of milk), and also because mass or energy balances can be calculated. Most of them comply with the LCA guidelines recently published by the International

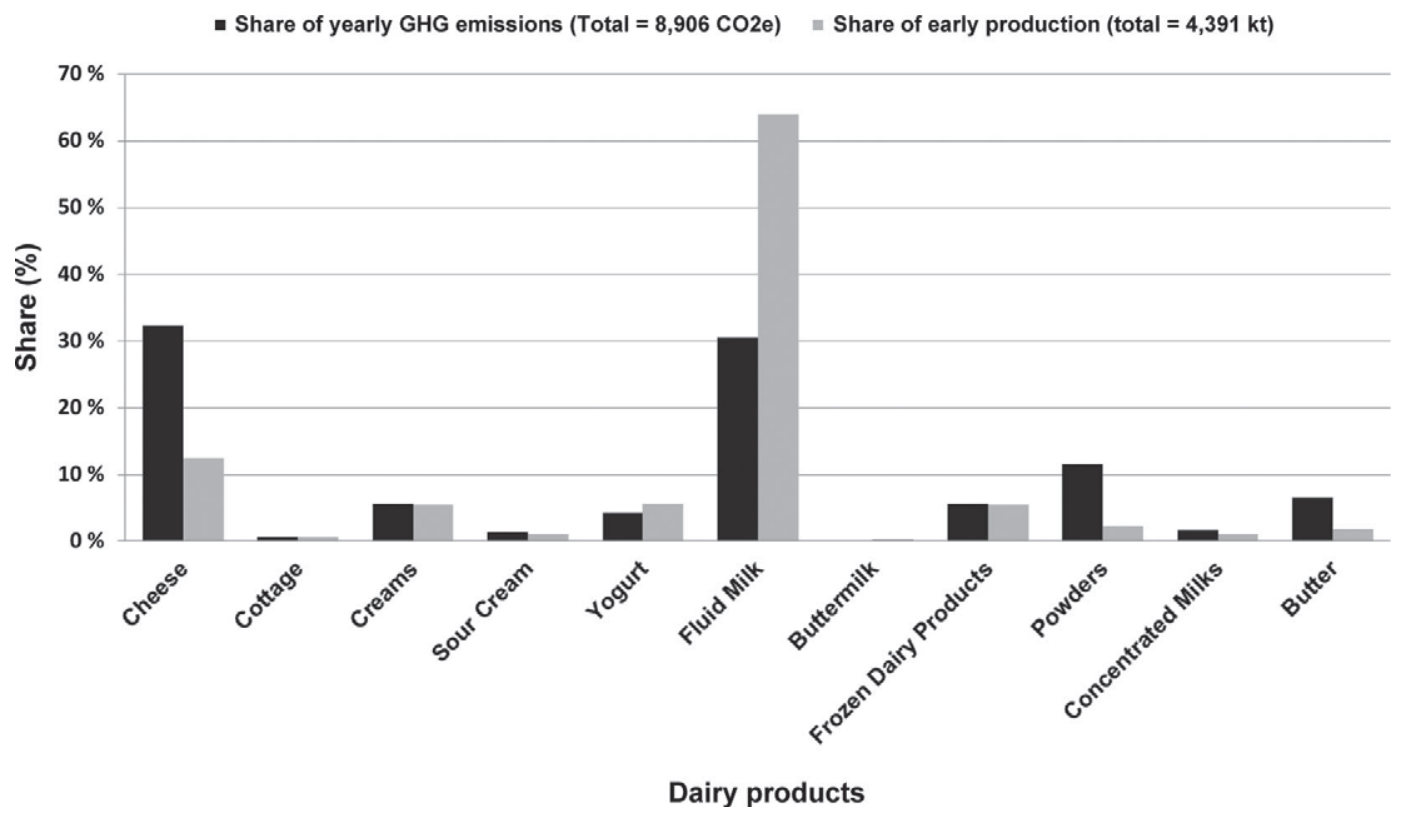

Figure 2. Annual (2006) production of dairy products in Canada and resulting greenhouse gas (GHG) emissions. 
Dairy Federation, which has recommended allocation approaches for the co-products encountered along the dairy production chain (IDF, 2010).

On-Farm Allocations. For the dairy industry, we used the allocation factors suggested by the International Dairy Federation (IDF, 2010). Therefore, 85.6\% of all GHG were allocated to milk production and $14.4 \%$ were attributed to meat from cows sold as culled mature animals and veal (grain- and milk-fed calves).

For soybean and canola meal used in animal rations, we used a mass allocation approach. For soybean, the oil percentage was provided by the Canadian Grain Commission (CGC, 2011). Analysis performed on soybean seeds grown in Canada showed that, on a DM basis, oil contents were $21.6 \%$. Therefore, GHG allocated to soybean meal was estimated to be 0.784 . For canola, seeds were estimated to contain $44.6 \%$ oil (CGC, 2011). However, these data correspond to oil content estimated on an $8.5 \%$ moisture basis. The allocation factor used was therefore estimated to be 0.487 .

Allocation for the Dairy Processing Industry. As previously mentioned, the dairy processing sector is considered as a whole and it is assumed that all dairy plants are multi-output integrated plants delivering the dairy product portfolio. Therefore, the dairy processing sector is considered to be one "box," and the allocation matrix (described below) is the "tool" that partitions inputs and effects of the co-products' portfolio (Figure 1). The approach developed by Feitz et al. (2007) for multi-products dairy plants was used. A physicochemical allocation matrix for 11 dairy products was developed for this study considering 6 inventory flows (raw milk and its transportation, total water use and wastewater generation, electricity, fossil fuels for thermal energy, alkaline cleaners, and acid cleaners). For raw milk, the allocation criterion was based on the degree of milk solids (fat, protein, lactose, and minerals) concentration in the final products. For other inventory flows, allocation criteria were derived from plant audits by the authors (Feitz et al., 2007). Because they are product-specific, packaging materials are not allocated but are individually assigned to the corresponding product. For all flows except raw milk input, Feitz's allocation factors have been applied to the dairy products chosen for this study (Table 2). This allocation method is the one recommended by the International Dairy Federation (IDF, 2010) and has been used by different authors (Flysjö et al., 2009; Lundie et al., 2009; Nilsson et al., 2010; Heller and Keoleian, 2011). For the raw milk input flow, which has the highest level of upstream GHG, we calculated Canadian-specific allocation factors. The milk solid concentration ratios were estimated for 34 dairy products (most are presented in Figure 2), based on the milk composition provided by the Canadian Nutrient File (Health Canada, 2011). The raw milk allocation factors were then calculated for these 34 products using production data from Dairyinfo (2011) and aggregated to obtain factors for the 11 main dairy products presented in Table 2 . This aggregation was necessary to be consistent with the Feitz's allocation matrix dimension (Feitz et al., 2007). Table 2 presents the allocation factors used for the dairy processing sector.

\section{Calculation of the Final Intensity Indicator}

Agricultural intensity indicators, which correspond to $\mathrm{CF}$, were calculated by dividing the total quantity of the allocated GHG emissions by the quantity of the agricultural product associated with these emissions. Units are kilograms of $\mathrm{CO}_{2} \mathrm{e}$ per kilogram of agricultural product. For comparison purposes, GHG emissions were also calculated per kilogram of protein (Dyer et al., 2010b). The final intensity indicator accounts for all GHG from cradle to the exit gate of the processing

Table 2. Factors (unitless) for allocating input and output inventory flows (columns) between dairy co-products (rows) for the transportation and the dairy processing step $^{1}$

\begin{tabular}{|c|c|c|c|c|c|c|}
\hline Dairy product & $\begin{array}{l}\text { Raw milk and raw } \\
\text { milk transportation }\end{array}$ & Electricity & $\begin{array}{l}\text { Fossil } \\
\text { fuel }\end{array}$ & $\begin{array}{l}\text { Water use and } \\
\text { waste water }\end{array}$ & $\begin{array}{l}\text { Alkaline } \\
\text { cleaners }\end{array}$ & $\begin{array}{c}\text { Acid } \\
\text { cleaners }\end{array}$ \\
\hline Cheese & 0.34 & 0.20 & 0.17 & 0.47 & 0.38 & 0.68 \\
\hline Cottage & 0.01 & 0.003 & 0.004 & 0.003 & 0.01 & 0.02 \\
\hline Sour cream & 0.01 & 0.004 & 0.004 & 0.004 & 0.004 & 0.001 \\
\hline Yogurt & 0.04 & 0.13 & 0.08 & 0.04 & 0.02 & 0.003 \\
\hline Fluid milk & 0.31 & 0.25 & 0.26 & 0.26 & 0.22 & 0.03 \\
\hline Powders & 0.10 & 0.07 & 0.34 & 0.07 & 0.10 & 0.16 \\
\hline Concentrated milks & 0.01 & 0.02 & 0.08 & 0.02 & 0.03 & 0.06 \\
\hline Butter & 0.07 & 0.02 & 0.04 & 0.02 & 0.01 & 0.05 \\
\hline All products & 1.00 & 1.00 & 1.00 & 1.00 & 1.00 & 1.00 \\
\hline
\end{tabular}

${ }^{1}$ For example, $34 \%$ of the $7,392,032,100 \mathrm{~L}$ of raw milk's GHG and raw milk transport's GHG are to be allocated to $547.8 \mathrm{kt}$ of cheese (data from Table 1). 
plant but the result is not the direct addition of the 3 intensity indicators (on-farm, transportation, and processing plant) calculated separately. Indeed they do not have the same unit: the first 2 are given per unit of farm product (raw milk) and the third is given per unit of manufactured product. Moreover, losses that have to be accounted for occur at different steps before the processing of the farm product, and imported farm products with their specific on-farm and transportation intensities have also to be accounted for. It has to be noted that no reported trading of raw milk occurs. Concerning losses, the underlying assumptions are that when loss of product occurs, the embedded GHG emissions are attributed to the remaining product. Although incidental, any loss is inherent to the demand of the product. For instance, if a processor needs $1 \mathrm{~L}$ of milk, the farmer will produce more than $1 \mathrm{~L}$ (e.g., 1.05 $\mathrm{L}$ ) in anticipation of the losses of raw milk to satisfy this demand. The GHG emissions embedded within this extra $0.05 \mathrm{~L}$ must thus be charged with the $1 \mathrm{~L}$ to be processed.

When data on losses were not precise enough to identify where they occurred between the farm and the processing plant, then the amount lost was assumed to be the same before transportation and after transportation and equal to half the amount lost.

The final intensity indicator $(C F)$ for each manufactured product $(P x)$ was calculated by adding the total amount of GHG emitted by the production (TotGH$G_{\text {Farm }}$ ) and transportation ( $T o t G H G_{\text {Trsp }}$ ) of the farm outputs to the processing industry to all GHG from all other input and output flows of the industry for the year considered $\left(T o t G H G_{\text {Ind }}\right)$. A factor $(A F)$ is then used to allocate this total to each manufactured product $(P x)$ coming out of this industry. Once allocated, the respective total of allocated GHG is divided by the total yearly weight of the product. These calculations can be summarized as follows:

$C F_{P x}=\frac{\left(T o t G H G_{F a r m}+T o t G H G_{T r s p}+T o t G H G_{I n d}\right) \times A F_{P x}}{k g \text { of } P x}$.

Presenting the results per kilogram of product could, however, be misleading for future comparison with nondairy products, such as soymilk. To avoid this limitation, we also calculated the amount of GHG produced per kilogram of protein content. The percentage of protein used in calculations is presented in Figure 3. When the product listed was a generic product, the value corresponded to a weighted percentage of the protein content of each of the identified subproducts. For the frozen dairy product category, data on the percentage of protein were not available for all subproducts and this generic category was therefore not considered. The protein percentages came from Milk Ingredients (2012), except for buttermilk, whose percentage was provided by Health Canada (2012).

\section{RESULTS}

The following section presents the total GHG emissions and the intensity indicators. The GHG emissions for the on-farm and off-farm activities are presented for the raw material (raw milk) and for dairy products.

\section{Total GHG Emissions}

Table 3 presents the total GHG emissions for all 3 agricultural GHG $\left(\mathrm{CH}_{4}, \mathrm{~N}_{2} \mathrm{O}\right.$, and $\left.\mathrm{CO}_{2}\right)$ in tonnes of $\mathrm{CO}_{2} \mathrm{e}$ for the year 2006 and shows the share of emissions (\%) coming from on-farm and off-farm activities. It also presents the dairy animal population for the same year. This population takes all dairy categories into account, including lactating (cows) and nonlactating categories such as bulls, heifers for replacement, and calves, as they are all needed to be able to keep producing milk over years. The number of cows alone represents on average of about $50 \%$ of these populations (with a minimum of $48 \%$ in Ontario and a maximum of $55 \%$ in British Columbia).

In Canada, most of the dairy animals are raised in the east and, because emissions depend mainly on the animal population, most of the GHG emissions from the dairy industry occur in these provinces (around $78.5 \%$ ). Of these emissions, over $90 \%$ are emitted onfarm. Important differences exist between provinces: the extremes are Alberta and Québec, where the share in the on-farm emissions varies from 83 to $94 \%$, respectively.

The electricity emission factors (EF), which have a large effect on the off-farm emissions, are presented in Table 3. These EF include all indirect emissions from resource extraction, primary energy production and supply, electricity production in power plants, and electricity distribution and losses; they include infrastructure-related emissions. Processes were modeled from the Ecoinvent LCI database; therefore, the values presented here differ from those presented in the National Inventory Report (Environment Canada, 2012).

\section{GHG Intensity Indicators}

Raw Milk. Table 4 presents the intensity indicators for the production of raw milk. The indicators account for all on-farm GHG emissions allocated to milk and GHG due to the transportation of milk from the farm to the processing plant. No emissions from the 
Table 3. Total on-farm and off-farm (transportation and processing plant) greenhouse gas emissions $\left(\mathrm{CO}_{2}\right.$ equivalents, $\left.\mathrm{CO}_{2} \mathrm{e}\right)$ from dairy cattle by region in 2006

\begin{tabular}{|c|c|c|c|c|c|}
\hline Region & $\begin{array}{l}\text { Animal population } \\
\left(\times 10^{6}\right)\end{array}$ & $\begin{array}{l}\text { Total emissions } \\
\left(\mathrm{Mt} \text { of } \mathrm{CO}_{2} \mathrm{e}\right)\end{array}$ & $\begin{array}{c}\text { On-farm } \\
\text { emissions (\%) }\end{array}$ & $\begin{array}{c}\text { Off-farm } \\
\text { emissions (\%) }\end{array}$ & $\begin{array}{c}\text { Electricity } \mathrm{EF}^{2} \\
\left(\mathrm{~kg} \text { of } \mathrm{CO}_{2} \mathrm{e} / \mathrm{kWh}\right)\end{array}$ \\
\hline Atlantic $^{3}$ & 0.11 & 0.56 & 89 & 11 & 0.593 \\
\hline Québec & 0.79 & 3.25 & 94 & 6 & 0.023 \\
\hline East $^{4}$ & 1.59 & 6.98 & 92 & 8 & - \\
\hline Manitoba & 0.08 & 0.35 & 93 & 7 & 0.054 \\
\hline Saskatchewan & 0.05 & 0.24 & 85 & 15 & 0.820 \\
\hline British Columbia & 0.13 & 0.60 & 92 & 8 & 0.046 \\
\hline West $^{6}$ & 0.43 & 1.92 & 88 & 12 & - \\
\hline Canada & 2.02 & 8.91 & 91 & 9 & 0.256 \\
\hline
\end{tabular}

${ }^{1}$ Includes cows, bulls, heifers, and calves.

${ }^{2}$ Emission factor.

${ }^{3}$ Includes all Atlantic Provinces.

${ }^{4}$ Includes Atlantic, Québec, and Ontario.

${ }^{5}$ Includes Manitoba, Saskatchewan, and Alberta.

${ }^{6}$ Includes Prairies and British Columbia.

processing step were included in these indicators; most of GHG emissions are produced on-farm. The share of the milk transportation represented from $2.21 \%$ in the Atlantic Provinces to $2.63 \%$ in British Columbia, with a Canadian average of about $2.5 \%$.

The average intensity indicator for Canada was 1.1 $\mathrm{kg}$ of $\mathrm{CO}_{2} \mathrm{e} / \mathrm{L}$ of raw milk produced and varied between
0.88 and 1.17 in British Columbia and the Atlantic Provinces, respectively. On average, the highest values were found in the west with $1.15 \mathrm{~kg}$ of $\mathrm{CO}_{2} \mathrm{e} / \mathrm{L}$ of milk compared with $0.95 \mathrm{~kg}$ of $\mathrm{CO}_{2} \mathrm{e} / \mathrm{L}$ of milk in the east.

Dairy Products. As shown in Figure 2, fluid milk, cheese, yogurt, ice cream, and cream are the major dairy products processed in Canada. Fluid milk is by

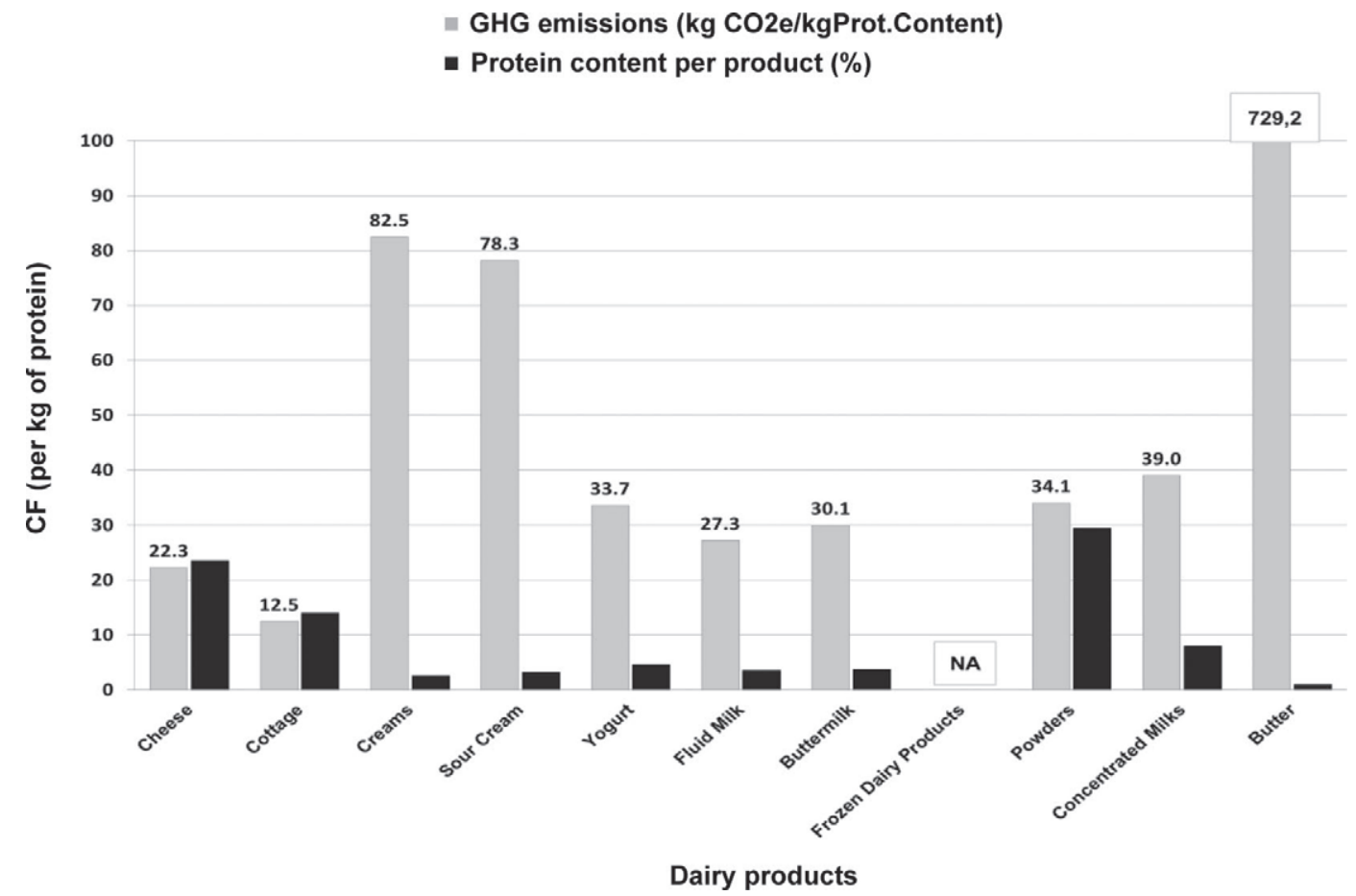

Figure 3. Carbon footprint of Canadian dairy products expressed per kilogram of protein content. $\mathrm{GHG}=$ greenhouse gas; $\mathrm{CO}_{2} \mathrm{e}=\mathrm{CO}_{2}$ equivalents; $\mathrm{NA}=$ not applicable (the range of the protein percentage of this food category was too large). 
Table 4. Intensity indicator $\left[\mathrm{kg}\right.$ of $\mathrm{CO}_{2}$ equivalents $\left(\mathrm{CO}_{2} \mathrm{e}\right) / \mathrm{L}$ of milk] of raw milk by region in 2006

\begin{tabular}{lcc}
\hline Region ${ }^{1}$ & $\begin{array}{c}\text { On-farm intensity } \\
\text { indicator }\end{array}$ & Total GHG ${ }^{2}$ \\
\hline Atlantic & 1.14 & 1.17 \\
Québec & 1.11 & 1.14 \\
Ontario & 1.12 & 1.15 \\
East & 1.12 & 1.15 \\
Manitoba & 1.05 & 1.07 \\
Saskatchewan & 0.94 & 0.96 \\
Alberta & 0.95 & 0.97 \\
Prairies & 0.97 & 1.00 \\
British Columbia & 0.86 & 0.88 \\
West & 0.93 & 0.95 \\
Canada & 1.07 & 1.10 \\
${ }^{1}$ Regions as defined in Table 3. & \\
${ }^{2}$ On-farm + transportation only (no emission from the processing plant); GHG = greenhouse gas. Note: it is \\
possible to obtain the value associated with transportation only by subtracting the on-farm value from the \\
total GHG.
\end{tabular}

far the most important source for almost two-thirds of the annual tonnage. However, in terms of GHG, fluid milk and cheese account for about one-third of the emissions, followed by powdered products such as milk powder $(12 \%)$, butter, cream, and frozen products $(6 \%$ each).

Several of the dairy products presented in Figure 2 correspond to generic categories representing different types of production. For example, the cheese category combined the following group of products: Cheddar, Mozzarella, specialty cheese, and processed cheese. The fluid milk category includes milk with different fat content $(3.25,2,1 \%$, and skim milk), buttermilk, chocolate milk, and eggnog. In 2006, $2 \%$ fat milk accounted for almost half of the fluid milk production, followed by $1 \%$ fat milk (22\%), 3.25\% fat milk (15\%), skim milk (10\%), and chocolate milk (7\%).

The intensity indicators for each of the product listed in Figure 2 are presented by region and for Canada overall in Table 5. Considering the results obtained in Table 4, it was not surprising to find the lowest intensity indicator in British Columbia and the highest in the Atlantic. Also, intensities were generally higher in the east than in the west. Most of the intensity indicators were between 1 and $3 \mathrm{~kg}$ of $\mathrm{CO}_{2} \mathrm{e} / \mathrm{kg}$ of product. Three products had, however, significantly higher intensity indicators: cheese $\left(5.3 \mathrm{~kg}\right.$ of $\left.\mathrm{CO}_{2} \mathrm{e} / \mathrm{kg}\right)$, butter $(7.3 \mathrm{~kg}$ of $\mathrm{CO}_{2} \mathrm{e} / \mathrm{kg}$ ), and powders (10.1 kg of $\mathrm{CO}_{2} \mathrm{e} / \mathrm{kg}$ ).

Emissions on a protein basis and protein content per product are presented in Figure 3. Most of the values were between 13 and $40 \mathrm{~kg}$ of $\mathrm{CO}_{2} \mathrm{e} / \mathrm{kg}$ of protein. Two products had higher values: cream and sour cream with 83 and $78 \mathrm{~kg}$ of $\mathrm{CO}_{2} \mathrm{e} / \mathrm{kg}$ of protein, respectively. However, the highest value was for butter, with about 730 $\mathrm{kg}$ of $\mathrm{CO}_{2} \mathrm{e} / \mathrm{kg}$ of protein. This extremely high value is due to the high emissions in this intensity indicator and to butter being almost exclusively fat (protein content is $1 \%$ ).

Table 5. Carbon footprint $\left[\mathrm{kg}\right.$ of $\mathrm{CO}_{2}$ equivalents $\left(\mathrm{CO}_{2} \mathrm{e}\right) / \mathrm{kg}$ of product] by region for several nonpackaged dairy products in 2006

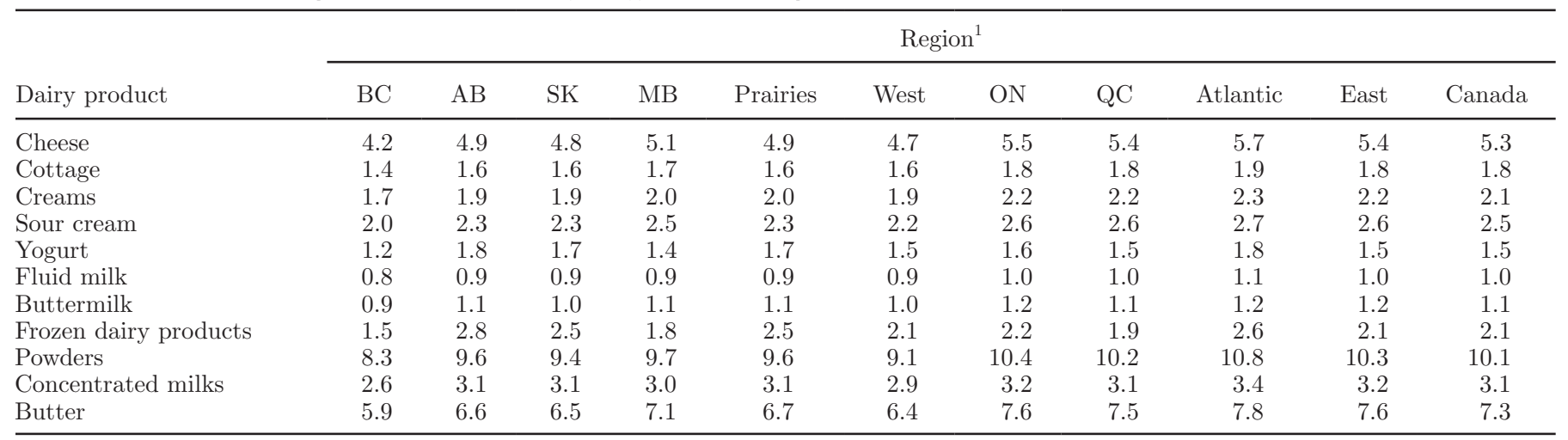

${ }^{1} \mathrm{BC}=$ British Columbia; $\mathrm{AB}=$ Alberta; $\mathrm{SK}=$ Saskatchewan; $\mathrm{MB}=$ Manitoba; Prairies = weighted average for Manitoba, Saskatchewan, and Alberta; West $=$ Prairies and British Columbia; ON = Ontario; QC = Québec; Atlantic $=$ all Atlantic Provinces; East $=$ Atlantic, Québec, and Ontario. 
Table 6. Detailed greenhouse gas (GHG) emissions (\% of total) by production steps and processing for 2 dairy products in 2006

\begin{tabular}{lcc}
\hline Step & Fluid milk $^{1}$ & Yogurt $^{2}$ \\
\hline Farm production & 86.9 & 72.2 \\
Transportation & 1.0 & 0.9 \\
Processing & 6.5 & 16.8 \\
Packaging & 5.5 & 10.1 \\
Total & 100 & 100 \\
Processing (detailed) & 28.5 & \\
Electricity & 66.6 & 41.0 \\
Fossil fuels & 1.6 & 57.3 \\
Water and wastewater & 1.5 & 0.7 \\
Cleaners & 1.9 & 0.3 \\
Refrigerants & 100 & 0.7 \\
Total & & 100 \\
\hline
\end{tabular}

${ }^{1}$ Total emissions including packaging $=1.00 \mathrm{~kg}$ of $\mathrm{CO}_{2}$ equivalents $\left(\mathrm{CO}_{2} \mathrm{e}\right) / \mathrm{kg}$ of fluid milk; packaged in polycoated carton $(0.5 \mathrm{gal})$.

${ }^{2}$ Total emissions including packaging $=1.75 \mathrm{~kg}$ of $\mathrm{CO}_{2} \mathrm{e} / \mathrm{kg}$ of yogurt; packaged in polystyrene tubs $(4 \times 125 \mathrm{~g})$.

All GHG emissions presented in the previous section and in Figure 3 did not include the packaging effect. For completeness and to be able to evaluate hot spots and identify mitigation practices, the effect of the packaging production on the total GHG emissions within the boundaries of the study was estimated. The calculations were performed for 2 products with very different effects: a low-processed product, fluid milk, and a more-processed product, yogurt. Table 6 presents the results categorized by source.

For off-farm emissions, the most important source was processing, followed by packaging and transportation. Percentages were higher for yogurt than for fluid milk, and the difference between the processing and packaging sources was also greater for yogurt than for fluid milk. Table 6 also details emissions for the processing step. Fossil fuel and electricity use was, by far, the greatest contributor. Fossil fuel was the highest for the 2 products, but the difference with electricity was smaller for yogurt, which relies more on electric processing than fluid milk.

\section{DISCUSSION}

\section{GHG Emissions-Sources and Trends}

Total emissions observed per province (Table 3) reflect the provincial level of milk production. Québec and Ontario, totaling more than $70 \%$ of the national production, emit almost 4 times more GHG than all the other provinces together. Most of the emissions (about 90\%; Table 3) are related to agricultural production. Important differences exist, however, among the provinces: the share of GHG emissions from off-farm activities goes from $6 \%$ in Québec to $17 \%$ in Alberta. These differences depend on both on-farm and off-farm production efficiencies.
The on-farm efficiency is presented in Table 4 through the intensity indicator. Québec, Ontario, and, to a lesser extent, Manitoba, showed relatively high indicator values, which explains the high on-farm percentage presented in Table 3. This was essentially due to the higher $\mathrm{N}_{2} \mathrm{O}$ emission because of the wetter climate in these regions. It was also correlated to the regional specificities observed in the Canadian dairy sector. The animal population is much lower in western provinces than in eastern ones and the dairy sector is, on average, more industrialized. For instance, the cow percentage of the dairy herd is higher in the west (55\%) than in the east (49\%), which means that nonmilking animals (bulls, heifers, and calves) are less represented and milk efficiencies, in regard to GHG emissions, are higher. Also, Holstein is the main breed across Canada because it is the most productive dairy breed, but the eastern dairy herd is more diversified: 5 breeds are well represented in Québec (eastern province) whereas only 1, Holstein, is raised in Saskatchewan (western province). It is advantageous to be able to diversify dairy products (Dairyinfo, 2012); however, because high milk yield is generally correlated to low carbon footprint (Kristensen, 2011), this situation has greater benefit for the western provinces, where the most productive dairy cattle are found $(7,700$ vs. $7,300 \mathrm{~L}$ of milk as weighted average for west and east, respectively).

The average Canadian $\mathrm{CF}$ was $1.07 \mathrm{~kg}$ of $\mathrm{CO}_{2} \mathrm{e} / \mathrm{L}$ of milk, ranging from 0.86 to $1.14 \mathrm{~kg}$ of $\mathrm{CO}_{2} \mathrm{e} / \mathrm{L}$ of milk (Table 4). This result is close to the average value reported by European studies (Gerber et al., 2010a) and similar to that calculated by Williams et al. (2006) for conventional dairy farms in England and Wales (1.06 $\mathrm{kg}$ of $\mathrm{CO}_{2} \mathrm{e} / \mathrm{L}$ of milk). In this "cradle to farm gate" study, Williams et al. (2006) showed that organic farms had a higher $\mathrm{CF}$ (1.23 $\mathrm{kg}$ of $\mathrm{CO}_{2} \mathrm{e} / \mathrm{L}$ of milk). However, this lower efficiency does not necessary reflect the true environmental impact because organic farmers produce more meat per kilogram of milk (Flysjö et al., 2012). It is also interesting to note that Cederberg and Mattson (2000) found that the global warming potential of organic milk was about $13.6 \%$ lower than that of milk from conventional milk production.

When no on-farm positive relationship, (i.e., high indicator value, Table 4, with high percentage, Table 3) was observed, results were mainly dependent on off-farm efficiencies. This was the case for Alberta, Saskatchewan, the Atlantic Provinces, and British Columbia, where off-farm energy use was the main parameter to consider. It represented 95.1 and $98.3 \%$ of the processing emissions, depending on the product (Table 6).

Energy can be divided into 2 groups: fossil fuels (mostly natural gas) and electricity. It is assumed 
that the energy efficiency of boilers is the same across Canada; thus, emissions associated with fossil fuel combustion do not differ from one province to another. Conversely, indirect GHG emissions from electricity production vary significantly across the provinces depending on the mix of electricity production (Table 3). In Alberta, where electricity is mainly based on the use of fossil energy, the EF is the highest. For British Columbia, it is the second lowest (after Québec), and in the Atlantic Provinces the third highest (after Alberta and Saskatchewan; Table 3). Therefore, provinces having low electricity EF, such as British Columbia, tend to have low off-farm emissions. Those with high EF, such as Alberta and the Atlantic Provinces, tend to have relatively high off-farm emissions.

The on-farm part of milk production and energy use during processing are the 2 largest contributors to the total GHG emissions of the dairy industry in Canada. As a result, any dairy product requiring a large amount of milk and its solids per kilogram and for which processing is energy intensive will show a higher CF than any minimally processed product necessitating a low amount of raw milk per kilogram. For instance, milk solids content per kilogram of butter, Cheddar, and skim milk powder are 1.2, 5.1, and 7.9 times higher, respectively, than that of raw milk. Conversely, the milk solids concentration factor for yogurt is only 1.2 (Health Canada, 2011). The CF pattern (Table 5) shows that fluid milk (mostly $2 \%$ fat milk) has the lowest $\mathrm{CF}$, whereas cheese, butter, and powdered products have $\mathrm{CF} 5,7$, and 10 times higher, respectively, and yogurt only 1.5 times higher. Note that results could be slightly different because emissions from additives (e.g., sugar, salt, stabilizers) were not accounted for in these calculations because of the lack of data. Concerning yogurt, these values are in a good agreement with those obtained by Büsser and Jungbluth (2009). Those authors calculated a $\mathrm{CF}$ of $2 \mathrm{~kg}$ of $\mathrm{CO}_{2} \mathrm{e} / \mathrm{kg}$ of product but the boundaries of the study were from "cradle to the consumer fridge." The yogurt production only (including milk production and its fermentation to yogurt in dairies) was estimated to represent about $60 \%$ of the total emissions or $1.2 \mathrm{~kg}$ of $\mathrm{CO}_{2} \mathrm{e} / \mathrm{kg}$ of product.

Thermal treatments such as evaporation and pasteurization are the most energy intensive processes in the food industry. Evaporation is involved in the production of condensed products and powders (e.g., milk powder or whey powder). Although a far less significant source of GHG than milk production, emissions from thermal treatments (through fossil fuel combustion for heat production) add up to that of the raw milk (Table 6 ). Therefore, the contribution of the processing step to the carbon footprint is much more pronounced for yogurts (which undergo a much more severe pasteuriza- tion than fluid milk, plus an incubation thermal rest), around $16.8 \%$ (Table 6 ). The processing step is also important for frozen products, but the emissions are mostly related to use of electricity for freezing and low temperature storage.

\section{Reporting Units}

In this study, the CF results were presented using 2 different units: per kilogram of product and per kilogram of protein content. When comparing fluid milk and yogurt footprints, the $\mathrm{CF}$ of yogurt was $55 \%$ higher than that of milk when reported per kilogram of product (1.5 vs. $1.0 \mathrm{~kg}$ of $\mathrm{CO}_{2} \mathrm{e} / \mathrm{kg}$ ), but only $23 \%$ higher when reported per kilogram of protein because of the higher protein density in yogurt than in fluid milk. For cheese and cream, results were not only different in magnitude but also reversed: 5 and $2 \mathrm{~kg}$ of $\mathrm{CO}_{2} \mathrm{e} / \mathrm{kg}$ of product for cheese and cream, respectively (Table 5), and 22 and $83 \mathrm{~kg}$ of $\mathrm{CO}_{2} \mathrm{e} / \mathrm{kg}$ of protein content (Figure $3)$. The most important and critical change occurred for butter. Because this product has very low protein per unit of mass, emissions are extremely high per unit of protein: about $7 \mathrm{~kg}$ of $\mathrm{CO}_{2} \mathrm{e} / \mathrm{kg}$ of product and 729 $\mathrm{kg}$ of $\mathrm{CO}_{2} \mathrm{e} / \mathrm{kg}$ of protein content. Therefore, because results are directly linked to the reporting unit, the way that the environmental impact of products is reported could lead to very different interpretations. Hence, for a meaningful comparison of the environmental footprint of foods, it is recommended to first identify the main function of the product - what main source of nutrient is the product providing and for which nutrient(s) is the product consumed?-before choosing the relevant reporting unit and making a comparison with other food products. In practice, dairy products serve several functions depending on the product, and functions would have to be identified for each of them, such as source of protein, source of fat, or source of carbohydrate. For instance, fluid milk, yogurt, or cheese would be compared with protein-rich competitors such as red meat, poultry meat, or legumes on a protein content basis, whereas butter and cream would be more logically compared with vegetable oils and spreads on a fat content basis. A more thorough study should consider the nutritional balance of the product with respect to dietary reference intakes (all fat, all carbohydrates, or all protein are not equal from a diet perspective), as well as the technological function a food ingredient can serve (e.g., milk and meat are not fully substitutable because milk is an ingredient for various recipes, whereas meat is not).

However, the question of the reporting unit arises differently when no comparison is sought and when the environmental impact is only assessed to establish the 
profile of a specific product. In this case, the objective is not to compare the environmental merits of two (or more) specific products but to study the environmental impact of a given production. The choice of the reporting unit is then crucial because it greatly influences the results.

\section{CONCLUSIONS}

Having set the boundaries of this study from cradle to the exit gate of the processing plant, the on-farm contributions were estimated to be about 90\% (Canadian average) of total GHG emissions. Variations between provinces were related to on-farm practices and environmental conditions, such as climate, and, to a lesser extent, off-farm parameters such as energy source. The on-farm emissions are potentially better controlled by the dairy sector than off-farm emissions because they are mainly related to farm practices and less by uncontrollable parameters such as weather. Off-farm emissions are mainly linked to the use of energy, primarily electricity. In the present study, GHG emissions from industrial wastewater treatments were estimated but this aspect of the modeling deserves improvement, thereby allowing consideration of the abatement potential of the associated mitigation practices. However, the contribution to the total emissions is relatively low. Finally, for comparison purposes, the reporting unit must be defined on the basis of the function of the food products and a comparison of all products presented cannot be done. This study indicated that any interpretation based on the current units (mass of product or protein content) might not be ideal when reporting emission intensities for food products. A protein basis was used in this study, but a similar problem would be encountered if using the percentage of either fat or carbohydrate. Functionality has to be considered, but it might be insufficient for food product labeling because different reporting units (adapted to a specific food product) will be used, and the resulting confusion could lead consumers to lose confidence in such labeling. One common function to describe all of these products is the need to feed people. Therefore, is it also possible to find a common reporting unit for all food products? A standardized methodology will certainly have to be developed and a more comprehensive approach will have to be used. More research is therefore needed to explore this very important LCA topic.

\section{REFERENCES}

ASAE. 2003. Manure production and characteristics: Standard D384.1. American Society of Agricultural Engineers (ASAE), St. Joseph, MI.

Brachfeld, D., T. Dritz, S. Kodama, A. Phipps, and E. Steiner. 2001. Life cycle assessment of the Stonyfield Farm product delivery system. Report CSSS01-03, The Center for Sustainable Systems, Uni- versity of Michigan, Ann Arbor. Accessed June 14, 2013. http:// css.snre.umich.edu/css_doc/CSS01-03.pdf.

British Columbia Dairy Council. 2008. Milk Container Recycling Program Status Report. Accessed June 14, 2013. http://www.milkcontainerrecycling.com/BC/documents/StatusreportMar3108.pdf.

Büsser, S., and N. Jungbluth. 2009. The role of flexible packaging in the life cycle of coffee and butter. Int. J. Life Cycle Assess. 14:80-91.

Cederberg, C., and B. Mattson. 2000. Life cycle assessment of milk production-A comparison of conventional and organic farming. J. Clean. Prod. 8:49-60.

CGC (Canadian Grain Commission). 2011. Harvest and export quality reports on Canadian grain. Accessed June 15, 2013. http://www. grainscanada.gc.ca/quality-qualite/geuq-quf-eng.htm.

CIEEDAC (Canadian Industrial Energy End-Use Data and Analysis Centre). 2010. Energy Consumption and Energy Intensity Indicators database, NAICS Industry 311500 Dairy Product Manufacturing. Accessed June 14, 2013. http://www2.cieedac.sfu.ca/index. html.

CNE (Conseil National de l'Emballage). 2007. Emballages et suremballages des yaourts et autres produits laitiers ultra-frais. Accessed June 14, 2013. http://www.conseil-emballage.org/Img/ Publications/8.pdf.

Dairyinfo. 2011. Canadian Dairy Information Centre. Accessed June 14, 2013. Manufacturing of dairy products. http://www. dairyinfo.gc.ca/index_e.php?s1=dff-fcil\&s2=proc-trans\&s $3=$ psdp-pvpl\&page=intro. Milk production at the farm. http:// www.dairyinfo.gc.ca/index_e.php?s1=dff-fcil\&s2=farm-ferme\&s3 =prod. Milk volumes and components. http://www.dairyinfo. gc.ca/index_e.php?a1=dff-fcil\&s2=msp-lpl\&s3=volume.

Dairyinfo. 2012. Canadian Dairy Information Centre: Statistics of the Canadian dairy industry. http://www.dairyinfo.gc.ca/index_e. php?s1 $=$ pb\&menupos $=1.4$.

Dyer, J. A., and R. L. Desjardins. 2003. Simulated farm fieldwork, energy consumption and related greenhouse gas emissions in Canada. Biosystems Eng. 85:503-513.

Dyer, J. A., and R. L. Desjardins. 2007. Energy-based GHG emissions from Canadian agriculture. J. Energy Inst. 80:93-95.

Dyer, J. A., and R. L. Desjardins. 2009. A review and evaluation of fossil energy and carbon dioxide emissions in Canadian agriculture. J. Sustain. Agric. 33:210-228.

Dyer, J. A., S. N. Kulshreshtha, B. G. McConkey, and R. L. Desjardins. 2010a. An assessment of fossil fuel energy use and $\mathrm{CO}_{2}$ emissions from farm field operations using a regional level crop and land use database for Canada. Energy 35:2261-2269. http:// dx.doi.org/10.1016/j.energy.2010.02.013.

Dyer, J. A., X. P. C. Vergé, R. L. Desjardins, and D. Worth. 2008 Long term trends in the GHG emissions from the Canadian dairy industry. Can. J. Soil Sci. 88:629-639.

Dyer, J. A., X. P. C. Vergé, R. L. Desjardins, and D. E. Worth. 2010 b. The protein-based GHG emission intensity for livestock products in Canada. J. Sustain. Agric. 34:618-629. http://dx.doi.org/10.1 080/10440046.2010.493376.

Eide, M. H. 2002. Life cycle assessment (LCA) of industrial milk production. Int. J. Life Cycle Assess. 7:115-126.

Elward, M., B. McLaughlin, and B. Alain. 2003. Livestock Feed Requirements Study 1999-2001. Catalogue No. 23-501-XIE, Statistics Canada, Ottawa, ON, Canada.

Environment Canada. 2012. National Inventory Report 1990-2010: Greenhouse gas sources and sinks in Canada-Part 3. Environment Canada. Accessed June 15, 2013. unfccc.int/files/national_reports/ annex_i_ghg_inventories/national_inventories_submissions/ application/zip/bgr-2012-nir-12apr.zip.

Feitz, A. J., S. Lundie, G. Dennien, M. Morain, and M. Jones. 2007. Generation of an industry-specific physico-chemical allocation matrix. Int. J. Life Cycle Assess. 12:109-117.

Flysjö, A., C. Cederberg, and J. D. Johannesen. 2009. Carbon Footprint and Labelling of Dairy Products - Challenges and opportunities. Proc. Joint Actions on Climate Change Conference, Aalborg, Denmark. Accessed June 15, 2013. http://www.dairy footprint.org/research/file-cabinet. 
Foster, C., K. Green, M. Bleda, P. Dewick, B. Evans, A. Flynn, and J. Mylan. 2006. Environmental impacts of food production and consumption: A report to the Department for Environment and Rural Affairs. Manchester Business School. Defra (Department for Environment and Rural Affairs), London, UK.

Gerber, P., T. Vellinga, C. Opio, B. Henderson, and H. Steinfeld 2010a. Greenhouse Gas Emissions from the Dairy Sector, A Life Cycle Assessment. Food and Agriculture Organization of the United NAtions (FAO), Animal Production and Health Division, Rome, Italy.

FPLQ (Fédération des Producteurs Laitiers du Québec). 2007. Annual report 2006. http://www.lait.org/en/the-federation/annualreport.php.

Health Canada. 2011. Canadian nutrient file (CNF). Accessed June 14, 2013. http://www.hc-sc.gc.ca/fn-an/nutrition/fiche-nutridata/index-eng.php.

Health Canada. 2012. Food and nutrition-Products \#124 and 5487. Accessed June 14, 2013. http://webprod3.hc-sc.gc.ca/cnf-fce/ index-eng.jsp.

Heller, M. C., and G. A. Keoleian. 2011. Life cycle energy and greenhouse gas analysis of a large-scale vertically integrated organic dairy in the United States. Environ. Sci. Technol. 45:1903-1910.

Hopkins, A., and M. Lobley. 2009. A scientific review of the impact of UK ruminant livestock on greenhouse gas emissions-A report for the NFU. Accessed June 15, 2013. http://socialsciences. exeter.ac.uk/media/universityofexeter/research/microsites/centre forruralpolicyresearch/pdfs/researchreports/Review_of_impact_ of_UK_livestock_on_GHGs_final_CRPR_report-27_1401-2009. pdf.

IDF. 2010. A common carbon footprint approach for dairy. The IDF Guide to Standard Lifecycle Assessment Methodology for the Dairy Sector. Bulletin of the International Dairy Federation 445/2010. Accessed June 14, 2013. http://www.idf-lca-guide. org/Files/media/Documents/445-2010-A-common-carbon-foot print-approach-for-dairy.pdf.

IPCC. 1996a. Revised 1996 IPCC Guidelines for National Greenhouse Gas Inventories: Reporting Instructions (Volume 1). Accessed June 15, 2013. http://www.ipcc-nggip.iges.or.jp/public/gl/invs4.html.

IPCC. 1996b. Revised 1996 IPCC Guidelines for National Greenhouse Gas Inventories: Reference Manual (Volume 3). Accessed June 15, 2013. http://www.ipcc-nggip.iges.or.jp/public/gl/invs6.html.

IPCC. 2000. Good practice guidance and uncertainty in national greenhouse gas inventories. Section 4: Agriculture. Intergovernmental Panel on Climate Change. Accessed June 15, 2013. http:// www.ipcc-nggip.iges.or.jp/public/gp/gpg-bgp.htm.

IPCC. 2006. Guidelines for national greenhouse gas inventories. Volume 4: Agriculture, Forestry and Other Land Use. Intergovernmental Panel on Climate Change,

ISO. 2006. ISO 14044: Environmental management-Life cycle assessment: Requirements and Guidelines. International Organization for Standardization (ISO), Geneva, Switzerland.

Kershaw, W., and J. Gaffel. 2008. The Australian Dairy Manufacturing Industry Sustainability Report 2007/2008. Accessed June 14, 2013. http://dmsc.com.au/wp-content/uploads/2011/03/ admsr0708.pdf.

Klein, K. K., and D. G. LeRoy. 2007. The biofuel frenzy: What's in it for Canadian agriculture? Green paper prepared for the Alberta Institute of Agrologists, Banff, Alberta, Canada. Department of Economics, University of Lethbridge, Lethbridge, Alberta, Canada.

Kristensen, T. 2011. Life cycle assessment of milk at farm gate-Focus on greenhouse gas emissions. EAAP 2011 Stavanger Norway. Accessed June 15, 2013. http://www.animalchange.eu/Docs/ Stavanger2011/S07_kristensen.pdf.

Lundie, S., M. Schulz, G. Peters, B. Nebel, and S. Ledgard. 2009. Fonterra Carbon Footprint Measurement-Methodology Report. The Centre for Water and Waste Technology, Scion and AgResearch. Report for Fonterra Cooperative Group Limited. Accessed June 14, 2013. http://www.fonterra.com/wps/wcm/connect/944cee004 15ae42c834eebd111458f1c/Carbon\%2BFootprint\%2Bmethodology \%2Bfinal.pdf?MOD=AJPERES.
Maxime, D., Y. Arcand, D. Landry, and M. Marcotte. 2010. Energy use and greenhouse gas emission. Pages 143-154 in Environmental Sustainability of Canadian Agriculture: Agri-Environmental Report Series. Report \#3. W. Eilers, R. MacKay, L. Graham and A. Lefebvre, ed. Agriculture and AgriFood Canada, Ottawa. Accessed June 15, 2013. http://publications.gc.ca/collections/ collection_2011/agr/A22-201-2010-eng.pdf.

Maxime, D., X. Vergé, Y. Arcand, and R. Desjardins. 2011. A cradleto-gate assessment of the carbon footprint of Canadian dairy products. Proc. LCA XI Conf., Chicago, IL. Accessed June 14, 2013. http://lcacenter.org/lcaxi/final/426.pdf.

Milk Ingredients. 2012. Dairy ingredient profiles. Accessed June 14, 2013. http://www.milkingredients.ca/index-eng.php?id=170.

Nilsson, K., A. Flysjö, J. Davis, S. Sim, N. Unger, and S. Bell. 2010. Comparative life cycle assessment of margarine and butter consumed in the UK, Germany and France. Int. J. Life Cycle Assess. 15:916-926.

Nutter, D., G. Thoma, R. Ulrich, M. Matlock, J. Popp, N. Kemper, Z Niederman, M. Faupel, M. Halsell, J. Johnson, and D. Shonnard. 2009. What is YOUR Carbon Footprint and Why Should You Care? International Dairy Foods Association 2009 Sustainability Workshop, Dallas, TX.

Polytainers. 2012. Polytainers Inc. products 510P, 514P, 516P, and $518 \mathrm{P}$ of the 500 Series catalogue. Accessed June 14, 2013. http:// www.polytainersinc.com/catalogue/series/500-series.

Rochette, P., D. E. Worth, R. L. Lemke, B. G. McConkey, D. J. Pennock, C. Wagner-Riddle, and R. L. Desjardins. 2008. Estimation of $\mathrm{N}_{2} \mathrm{O}$ emissions from agricultural soils in Canada-Development of a country-specific methodology. Can. J. Soil Sci. 88:641-654.

Steinfeld, H., P. Gerber, T. Wassenaar, V. Castel, M. Rosales, and C. de Haan. 2006. Livestock's Long Shadow-Environmental Issues and Options. FAO, Rome, Italy. Accessed June 15, 2013. http:// www.fao.org/docrep/010/a0701e/a0701e00.htm.

TetraPak. 2012. Calculating $\mathrm{CO}_{2}$ for a TetraPak carton. Characteristics for product Tetra Brik, square, $1000 \mathrm{~mL}$, simply pull opening and for Tetra Brik, edge, $1000 \mathrm{~mL}$, simply twist. Accessed June 14 2013. http://www.tetrapak.com/environment/climate_change/ co2footprint/carton_footprint/co2calculator/pages/default.aspx.

UNFCCC (United Nations Framework Convention on Climate Change). 2012. National Inventory Submissions. Accessed June 15, 2013. http://unfccc.int/national_reports/annex_i_ghg_inventories/national_inventories_submissions/items/6598.php.

Vergé, X. P. C., J. A. Dyer, R. L. Desjardins, and D. Worth. 2007. Greenhouse gas emissions from the Canadian dairy industry during 2001. Agric. Sys. 94:683-693.

Vergé, X. P. C., J. A. Dyer, R. L. Desjardins, and D. Worth. 2008 Greenhouse gas emissions from the Canadian beef industry. Agric. Sys. 98:126-134

Vergé, X. P. C., J. A. Dyer, R. L. Desjardins, and D. Worth. 2009a. Greenhouse gas emissions from the Canadian pork industry. Livest. Sci. 121:92-101.

Vergé, X. P. C., J. A. Dyer, R. L. Desjardins, and D. Worth. 2009b. Long-term trends in greenhouse gas emissions from the Canadian poultry industry. J. Appl. Poult. Res. 18:210-222.

Vergé, X. P. C., J. A. Dyer, D. E. Worth, W. N. Smith, R. L. Desjardins, and B. G. McConkey. 2012. A greenhouse gas and soil carbon model for estimating the carbon footprint of livestock production in Canada. Animals 3:437-454. http://dx.doi.org/10.3390/ ani2030437.

Vergé, X. P. C., D. Worth, J. Hutchinson, and R. L. Desjardins. 2006. Agri-environmental indicator-Greenhouse gas emissions from Canadian agro-ecosystems. Methane emissions. Technical report: Methodology for Calculations. Agriculture and Agri-Food Canada, Ottawa, ON, Canada.

Williams, A. G., E. Audsley, and D. L. Sandars. 2006. Determining the environmental burdens and resource use in the production of agricultural and horticultural commodities. Main Report. Defra Research Project IS0205. Cranfield University, Bedford, UK, and Defra, London, UK. Accessed June 15, 2013. http://www. cranfield.ac.uk/sas/naturalresources/research/projects/is0205. html. 